\title{
Prosecutorial Discretion and the Death Penalty: An Integral Perspective
}

\author{
Matthew T. Mangino ${ }^{1}$ and David R. Champion ${ }^{2, *}$ \\ ${ }^{1}$ Attorney at Law, New Castle, PA, USA \\ ${ }^{2}$ Slippery Rock University, USA
}

\begin{abstract}
The prosecutor's choice to pursue the death penalty is one of the most momentous decisions he or she will face. Capital punishment represents the ultimate power of the state over its citizenry, and the decision to take the life of an offender is fraught with moral complexity. This paper reviews some of the extant literature on the US death penalty in general and the particular issue of decision-making for prosecutors. Further, we introduce discussion on how Wilber's Integral theory might be applied to the topic. We present aspects of Integral theory, including the four quadrant model and what Wilber refers to as the Basic Moral Intuition (BMI), as possible tools that may be used to navigate the ethical difficulties surrounding this decision-making process. We anticipate that delving into aspects of the Integral theory and contemplating on how they relate to concrete issues of criminal prosecution may assist CJ practitioners in how they might find pathways to resolutions of ethical quandaries.
\end{abstract}

Keywords: Prosecutors, ethics, Integral theory, death penalty, capital punishment.

\section{THE ULTIMATE DECISION}

The most important decision a government can make is to take a human life. Yet the decision, in most jurisdictions, is left to a single person-an elected prosecutor (three states do not elect prosecutors and those states do not have the death penalty). The prosecutor's charging decision involves an enormous exercise of power-described by U.S Supreme Court Justice, and Nuremberg prosecutor, Robert H. Jackson as "the most dangerous power of the prosecutor" (Jackson, 1940, p. 5).

Thirty-two states and the federal government provide for the death penalty (DP). Those states have approximately 2,444 counties (Charleston County, 2011). Most of those counties, with some exceptions (see below), elect a district attorney. Each of those elected district attorneys can establish his or her own guidelines, or have no guidelines at all, for pursuing the death penalty.

The U.S. Supreme Court has never required procedures or guidelines be promulgated to control the process employed by prosecutors to reach the decision on life or death (DeMay, 1999). With potentially 2,444 different policies for pursuing the death penalty the possibility that bias in the form of race or ethnicity; politics; geography or even caprice may enter into the process. Such factors can lead to the arbitrary pursuit

*Address correspondence to this author at the Department of Criminology and Criminal Justice, Slippery Rock University, 016 Patterson Hall, Slippery Rock, PA 16057, USA; Tel: (724) 738-4462; Fax: (724) 738-4822;

E-mail: david.champion@sru.edu of the DP for some offenders and, conversely, the arbitrary exemption of someone otherwise eligible for the death penalty.

All 2,444 counties may not have an elected district attorney. For instance, the state of Tennessee is divided into ninety-five counties which are arranged into thirty-one judicial districts. Each judicial district has its own elected district attorney general. To assist with the responsibilities, the district attorney general may appoint assistant district attorneys general, (Tennessee Supreme Court, 2005). However, in every judicial district the voters have the right to keep or reject the prosecutor, be he or she from a county or wider judicial district.

No other legislative mandate delegates so much power, unguided by standards or policy, than the authority vested in county prosecutors. As James E. Lobsenz wrote in the Puget Sound Law Review, "The legislature has given prosecutors unfettered power to request execution, or not request executions, as they alone see fit" (Lobsenz, 1984, p.300). Prosecutors have been imbued with the moral conscience of their communities.

That may not necessarily be a bad thing if, for instance, as in most states, prosecutors are elected and the electorate is fully informed of the prosecutors position on the issue of capital punishment. Three states-Alaska, Connecticut and New Jersey-do not elect prosecutors and in Rhode Island the state attorney general acts as the state's district attorney. Those four states do not have the death penalty. 
In 1996, then New York Governor George Pataki intervened in a murder case in the Bronx, because the district attorney refused to seek the death penalty in a high profile case. Pursuant to state law the case was removed from the DA. He complained that the Bronx voters had been disenfranchised because his opposition to the death penalty was well known when he won election and reelection (Horowitz, 1997).

The removal of a DA from a specific case could not occur in a majority of states. In Pennsylvania the court could intervene to force a prosecutor to provide evidence in support of imposing the death penalty. If the court finds that there is not sufficient evidence the notice to pursue the death penalty can be stricken.

In 2012, Connecticut abolished the imposition of the death penalty in all future cases. Some of the 11 men who remain on the state's death row sued. In September, Chief State's Attorney Kevin T. Kane testified at the inmates' trial. According to The Hartford Courant, Kane testified that he was aware of informal discussions through the years among prosecutors about whether there should be formal guidelines for seeking the death penalty, ultimately "there were no specific policies directed to capital felony cases" (Kane, quoted by Griffin, 2012, para. 8).

Ohio's law provides prosecuting attorneys with the option of seeking the death penalty for murders that involve any of 10 specific aggravating factors.

Prosecutors also consider mitigating factors when making death penalty decisions. According to the Ohio Prosecuting Attorneys Association website those factors include the youth of the accused, duress, criminal record or "[l]f the defendant has a mental disease or didn't understand that what he was doing was a crime" (Ohio Prosecuting Attorneys Association, 2012).

The death penalty is to be reserved for the "worst of the worst." A prosecutor must assess the deservedness of the death penalty in light of all of the evidence, including the background of the alleged offender.

A study in Missouri found that about 76 percent of all homicides reviewed were death-eligible, yet prosecutors pursued capital trials in only about five percent of the cases. This appears to be a national trend. Prosecutors are less and less likely to seek the ultimate punishment (Barnes, Sloss \& Thaman, 2008).
Death sentences plunged in 2011 . Only 78 people were sentenced to death nationwide, the first time that number dropped below 100 since the death penalty was reinstated, according to the Death Penalty Information Center (2011).

In Texas, where about one-third of all executions nationwide are carried out, death sentences are dramatically down. Thirty-six killers were sentenced to death in Texas in 2002. Nine years later, that number was eight, according to the Waco Tribune (Witherspoon, 2012).In Ohio, prosecutors sought the death penalty 94 times in 2004. In 2012, that number fell to 56. According to the Cleveland Plain-Dealer, there were seven death sentences in Ohio in 2010, two in 2011 and three in 2012 (Marshall, 2012).

The reluctance of prosecutors to seek the death penalty may not necessarily represent a philosophical shift on punishment, but rather a pragmatic look at a costly and time consuming process that is being trumped by life in prison without the possibility of parole. For example, rather than take death penalty cases to juries, prosecutors in Idaho and Mississippi are opting not to pursue executions at all or are agreeing to plea deals that put killers in prison for life. Prosecutors have to weigh the high costs of pursuing the death penalty and the suffering of victims' families through years of appeals against the soaring expense of a death sentence (Everson, 2009).

Prosecutorial authority and influence goes beyond death penalty decisions. Prosecutors are among the most powerful figures in the criminal justice system. The proliferation of criminal statutes along with sentence enhancements and mandatory minimum sentencing have constricted the discretion and authority of judges and expanded the power of prosecutors.

The shift in power is no more evident than in the transition from a trial dominated system to one dependent on the negotiated plea. Recently, the New York Times provided a host of statistics that underscored this shift. The National Center for State Courts found that the percentage of felonies taken to trial, in the nine states with available data, fell to 2.3 percent in 2009, down from eight percent in 1976. That is fewer than one in 40 felony cases-35 years ago the ratio was about one in twelve (Oppel, 2011).

The shift is even clearer on the federal level. In 1977 , the ratio of guilty pleas to criminal trial verdicts in 
federal district courts was a little more than four to one; by 2011 , it was almost 32 to one.

Researchers found that prosecutors' decisions were guided by two basic questions: "Can I prove the case?" and "Should I prove the case?" The relative influence of these questions was found to shift over the course of a case. The first question was most influential at the outset of a case, where the objective strength of evidence was the determining factor in most screening decisions. Later, factors such as the seriousness of the offense, the defendant's criminal history, characteristics of the defendant and victim, and contextual factors became increasingly influential, as prosecutors evaluated whether a case should go forward.

While prosecutorial discretion is generally seen as very broad and unconstrained, prosecutors often rely on a fairly limited array of legal and quasi-legal factors to make decisions, not unlike making a decision of whether or not to seek the death penalty. These factors-rules, resources, and relationshipssometimes trump evaluations of the strength of the evidence, the seriousness of the offense, and the defendant's criminal history (Frederick \& Stemen, 2012).

How do prosecutors influence the plea bargaining process? Consider a defendant arrested within 1,000 feet of a school with a sizable amount of heroin and a gun. With mandatory sentencing for a large amount of heroin, enhancements for having a gun and being near a school, the defendant could theoretically face up to 12 years in prison. The defendant is offered a plea of five years or the option of trial with 12 years on the line. The judge has little leverage as she is bound by law to impose the mandatory penalties as well as the enhancements.

Researchers observed that the district attorneys had very few office-wide policies on case outcomes, although individuals units within these offices did have policies that limited discretion.

Prosecutors need guidelines for handling various common kinds of cases and evaluating the many factors that should impact their resolutions. But, having fixed rules for handling cases is counterproductive because they don't account for differences between individual cases.

When applied to the criminal justice system, rigidity has rarely proven to be a good idea. Similarly, inflexible policies in a district attorney's office that mandate certain offers or outcomes for certain kinds of cases could also result in injustices (Barton, 2013).

\section{PLEA BARGAINING AND PROSECUTION}

Defense attorneys claim that plea-bargaining in death-eligible cases rarely involve a sentence of life with the possibility of parole (LWOP). The majority of defense attorneys noted that the choice between a LWOP sentence and the possibility of advancing to a capital trial led them to advise their clients to plead guilty in order to avoid the death penalty (Petersen \& Lynch, 2012).

Many defense attorneys were fully aware of the power differential created by the threat of capital charges, characterizing pleas agreements in deatheligible cases as "take it or leave it" endeavors rather than actual "negotiations" (Petersen\& Lynch, 2012).

Prosecutors also acknowledged that the threat of capital punishment is frequently used to induce a guilty plea, even though nearly all denied ever engaging is such activities. Ultimately, the unequal power structure created by the capital plea-bargaining process may undermine defendants' rights regardless of whether or not prosecutors intentionally coerce defendants with the threat of capital charges.

"We now have an incredible concentration of power in the hands of prosecutors," Richard E. Myers II, a former assistant U.S. attorney and a professor at the University of North Carolina told the New York Times. He reported that so much influence now resides with prosecutors that "in the wrong hands, the criminal justice system can be held hostage (Oppel, 2011)."

This is not to suggest that all of that power is in the wrong hands. No other individual is better positioned to wield that power than a prosecutor. A prosecutor is keenly aware of the strengths and weaknesses of the state's case. The prosecutor has interviewed witnesses and thoroughly examined evidence. No figure in the justice system is in a better position to evaluate a case and decide what is fair.

For years, the U.S Supreme Court was reluctant to take on the plea bargaining process. "It is a very hard question why the Supreme Court is so sensitive to creating trial rights which make trial ever more complicated and therefore unworkable on the one hand, and on the other hand so insensitive to the resulting evasion which dominates the system," John Langbein, a Yale Law Professor, told Frontline (Public 
Broadcasting Service, 2004). Trial has become so complicated and time consuming that the criminal justice system would grind to a halt if every case went to trial. The plea bargain process provides a benefit to the defendant in the form of a more lenient sentence in exchange for a plea and prevents the collapse of an overburdened system.

Two recent U.S. Supreme Court decisions extend the Sixth Amendment right to competent representation by counsel to plea negotiations. Defense attorneys are now accountable for advice and counsel they provide went representing an accused during the plea bargaining process. A plea to avoid the death penalty may be applicable to the newly extended right to effective counsel during plea bargaining.

In Lafler v. Cooper (2012), the court was asked to review whether an attorney's advice to his client to reject a favorable plea bargain based on the lawyer's incorrect understanding of the law was ineffective assistance of counsel. In Missouri v. Frye,(2012), the court reviewed whether counsel's failure to disclose the terms of a favorable plea offer was a violation of the Sixth Amendment right to a fair trial.

Galin Frye was charged with a felony for driving with a revoked license. According to the opinion, he qualified for a public defender. The district attorney sent Frye's lawyer a letter offering a reduced charge and 90 days in jail. The lawyer never communicated the plea offer to Frye. Frye subsequently made an open plea and was sentenced to three years in prison. He filed a claim pursuant to the Sixth Amendment alleging ineffective assistance of counsel. The Court of Appeals agreed and the state of Missouri appealed (Missouri v. Frye, 2012).

In Anthony Cooper's case, a Michigan prosecutor communicated a verbal plea offer to Cooper's attorney. According to the opinion, Cooper would plead guilty and receive a recommended sentence of 51 to 85 months in prison. Cooper made it clear he would have accepted the plea. However, Cooper's attorney talked him out of accepting the plea based on a misunderstanding of the law (Laffler v. Cooper, 2012).

What will a defendant claiming ineffective assistance of counsel during plea negotiations have to prove? The court has established a three prong analysis. A defendant must prove he would have accepted the plea bargain if not for bad legal advice; there was a reasonable probability that prosecutors would not have withdrawn the offer before trial; and a judge would have ultimately accepted the plea (Mangino, 2012).

Justice Anthony Kennedy wrote for a 5-4 majority, "The reality is that plea bargains have become so central to the administration of the criminal justice system that defense counsel have responsibilities in the plea bargain process, responsibilities that must be met to render the adequate assistance of counsel that the Sixth Amendment requires" (Mangino, 2012).

The lack of any meaningful guidelines on death penalty decisions leads claims for selective prosecution. A decision to pursue the death penalty based upon an unjustifiable standard such as race, religion or arbitrary classification is selective prosecution. In order to show selective prosecution a party must show that the administration of the death penalty is directed so exclusively against a particular class of persons showing a denial of equal protection under the law (DeMay, 1999).

The decision to seek death must be a reasoned one. It must be consistent from case to case. The death decision must be guided by our duty to seek justice and to protect the public, (Little, 2012).

There is also the issue of vindictive prosecution. This occurs when a prosecutor uses the charging process to penalize the exercise of constitutional or statutory rights, thus resulting in a due process violation. A rebuttable presumption of vindictiveness is recognized whenever a prosecutor increases the number or severity of charges after a defendant asserts a legally protected right (DeMay, 1999).

It is an unavoidable outcome of prosecutorial discretion that the decision whether to seek the death penalty will be influenced by particular 'philosophical, ethical, religious or other views" of the district attorney. For example a prosecutor may dislike certain offenses or offenders for personal reasons, and the prosecutor may vary leniency on this basis. This creates a dangerous possibility "not accounted for in the assumption of rational, autonomous actors" (DeMay, 1999, p. 786).

While prosecutors engage in a cost-benefit analysis when deciding how to charge and pursue cases, the risk of losing in a capital case is mitigated by the fact that death-qualified juries are more conviction-prone than regular criminal juries. The chance of getting a conviction, particularly in cases with multiple special circumstances, is enhanced (Petersen\& Lynch, 2012). 
Analysis of prosecutorial discretion cannot ignore the so called "trial penalty." Some experts say the process has become coercive in many state and federal jurisdictions, forcing defendants to weigh their options based on the relative risks of facing a judge and jury rather than simple matters of guilt or innocence. In effect, prosecutors are giving defendants more reasons to avoid having their day in court.

"Legislators want to make it easy for prosecutors to get the conviction without having to go to trial," stated Rachel Barkow, a professor of law at New York University. "When you have that attitude," she told the New York Times, "you penalize people who have the nerve to go to trial" (Oppel, 2011).

What reasonably prudent defendant, represented by a reasonably competent attorney, would plead guilty if she knew a conviction at trial would bring the same penalty as pleading guilty. A defendant would have nothing to lose by going to trial.

Just as it is difficult to predict what might come from going to trial instead of taking a plea, it is equally difficult to predict what decision a prosecutor will make with regard to the death penalty.

The absence of uniform guidelines for seeking the death penalty on a federal, state or local level provides unfettered discretion to prosecutors. There is no road map-just a litany of decisions, often without rationale, to support the most important decision any government official will ever make.

In an essay of personal observations on the prosecution of capital cases, Sievert (1999) relates the criteria employed by his own office in making the decision to seek the death penalty among those who qualified for it under the statute. The first was for the involved prosecutors to satisfy themselves beyond "any possible doubt" (p. 107) that the defendant was guilty. The phrasing "any possible doubt" denotes a higher standard than the reasonable doubt required for conviction, and presumably approaches or meets the idea of moral certainty. After this initial assessment, Sievert discusses two standards to be considered: The power of the evidence, and whether the crime in question "cried out" for capital punishment (p. 107)

The first standard involves an evaluation of the strength of the evidence against the defendant, and includes tactical and technical considerations about witnesses, forensic examinations and investigative errors (Sievert, 1999).
The second standard is more pertinent to the current discussion because it involves a subjective/inter-subjective judgment that may be based in part on, but transcends, the technical considerations of statutes, codes and evidence. In this case the prosecutors must know "in (their) hearts that this person should die for what they did" and that the defendant was a "truly dangerous (and evil) human being" (Sievert, 1999, p. 108).

Gershman (1993) addresses the issue of moral standards and decision-making in the prosecutorial charging process, noting that the legal and ethical guidance provided to prosecutors is often insufficient. Constitutional and statutory considerations merely set up the bare legal parameters for the process, and ethical prescriptions that the prosecutor must "seek justice" are vague. And, as in any case of the exercise of discretion by criminal justice agents, specific policies and procedures cannot be expected to apply to all situations. Because human behavior is complex, multivariable and spans different social contexts, prosecutors (like police) must apply the law as best they can in variegated situations involving harmful or illegal behaviors. As Gershman notes, the decision encompasses consideration from a variety of domains, including ethical/moral, political, and legal ones. Pepinsky and Quinney (2001) state that much of prosecutorial powers may be abused as "war making" rather than "peacemaking," in that they make legal decisions that are geared more towards retribution rather than overall safety, control and peace.

Whether one takes a more Kantian retributive stance towards justice (which is generally perceived to be a lex talionis posture [Brooks, 2003]), or a more utilitarian approach (which reflects a more outcomebased objective for the criminal justice system, including recidivism, general deterrence and public safety concerns), it is clear that it is difficult to grasp a fundamental aspect of morality that prosecutors might use in order to seek justice and represent their community. However, the insufficiency of ethical and legal guidelines available to prosecutors suggests that an overarching perspective, such as the Integral map, may provide another tool for prosecutorial decisionmaking.

\section{AN INTEGRAL LENS}

Although the topic of prosecutorial decision-making in seeking the death penalty has been addressed through various discussions, it has yet to be examined 
from an Integral meta-theoretical perspective as set forth by contemporary philosopher Ken Wilber. The current work seeks to address this gap through discussion of aspects of prosecutorial decision-making and the death penalty through the theoretical lens of Wilber's Integral model. Wilber's Integral Theory (IT) The Integral model represents a meta-theoretical approach towards mapping the entirety of human knowledge and activities (as well as the processes of the physical world). It is an all-encompassing perspective that ambitiously covers the totality of human thought, development and potential through its four quadrant model. Although a thorough review of the wide-ranging aspects of IT surpasses the scope of this work, we will review a few elements of the metatheory's structure insofar as they apply to the machinations of the state's quest for the ultimate penalty.

The Integral model is a universal one that encompasses all aspects of human existence. The principles of IT have served as a useful discussion template to scholars and practitioners in the fields of business, the arts, psychology, and others (Wilber, $2000 ; 2003)$. Integral theory has been used as a framework for examining aspects of criminology/criminal justice in the past, including research methodology (Martin, Cohen \& Champion, 2013); theoretical orientation (Champion, 2011a; Gibbs, Giever \& Pober, 2000; Martin, 2006), and white collar crime (Champion, 2011b). However, it has not yet been applied to the particular question of legal ethics in the criminal justice system in regards to prosecutorial decision-making and capital punishment. The topic of prosecutorial decision-making and the death penalty has also been examined in extant literature (Gershman,1993; Sievert, 1999), but has not been discussed before from an Integral perspective. Because this specific issue can encompass all four domains of the All Quadrants/All Level (AQAL) Wilberian Integral map (see Figure 1) and because it involves the gravest dimensions of universal conceptions of justice, an exposition of this topic from an Integral perspective may provide insight into the nexus of law, morality and society.

In his Integral meta-theory, Wilber asserts that human conduct should include mindfulness of universal principles as well as how their actions affect not only their immediate environment, but other interconnected beings. This "great Chain of Being," "Great Web" or "Great Nest" are all metaphors for higher order morality and its concerns for the expansive principles of justice and care for what Wilber calls the Kosmos. (Kosmos is distinct from "cosmos" in that it includes living organisms and their modes of multi-spectrum development as well as the physical expanse of the natural world and universe) (Wilber, 1998; 2005).

Furthermore, the Integral framework includes and makes room for the synthesis of various stage-based theories of moral evolution, including Kohlberg's (1973; 1977), Gilligan's (1982), Piaget's (1932/1997), Gebser's (1985), and Graves' "spiral dynamics" (as expounded on by Beck \& Cowan, 1996). The common ground of these hierarchies of moral ascension includes a pre-conventional, conventional and postconventional progression. In general, these theories comprise an expansion of care from self-centeredness and gratification of one's own needs towards localized care (perhaps for one's family, community, or social network) and then evolve to universal notions of justice and/or care.

Finally, the four quadrant model is also an important element of this discussion. The quadrants are a depiction of the classic elements of human thought and actions: Arts, Morals and Science, also referred to as the Good, the True and the Beautiful. These "big three" value spheres (Wilber, 1998, p. 74; 2001, p. 70) represent the primary dimensions of human endeavors. The Good (Morals) is a line of development that resides in the lower left quadrant. This is the quadrant of inter-subjective collectivism and is also the home of the concepts of culture and the collective morality that underlies a society's spirit of justice. The right quadrants represent the external, empirical treatment of individual units (upper) and systems (lower). (Wilber, $1998 ; 2001)$. In this sense, the lower right is the realm of the technical, organized system of the machinations of the criminal justice process.

Because the Integral framework is so wide-ranging and encompasses so many perspectives of the nature of human behavior (as well as the physical world), it would be fallacious to represent this work as being "the" Integral perspective of this issue. It is only one perspective thereof. Bringing Wilber's vision to bear on individual aspects of human machinations, especially when it involves interpretation of moral judgment, necessitates a subjective posture on the part of the essayist. Therefore, this work should be regarded as only one of many possible pathways by which the focus of the Integral lens may be brought to bear onto realworld scenarios. A full summary of Integral Theory (IT) is outside the scope of this work, and readers are 
referred to the works of Wilber for further reading on the subject. However, there are two elements of IT that bear discussion on the current topic: Quadrants and levels of existence (see Figure $\mathbf{1}$ below).

The consideration of morality (particularly moral choices made by individuals operating within a sociocultural environment) may be considered as spanning both Left quadrants, comprising both individual/subjective intent (Upper Left) and the treatment of others within a social collective (Lower Left). The moral line of development operates in the LL subjective, because inherent in morality is the treatment of fellow beings (Wilber, 2000). It may also be thought of as a UL individual/subjective line of development, in that it involves the internal depths of the individual as he or she makes moral decisions.

All of this is to underscore the pertinence of Integral Theory as a wide-view lens with which the criminal justice discipline may be examined and discussed. In this case (specifically), we bring it to bear on the issues involved in the decision-making process of prosecutors in seeking the death penalty.

\section{APPLICABLE ELEMENTS OF INTEGRAL THEORY}

\section{Quadrants: The Mapping of Reality}

A society's laws and justice system are functions of both of the lower quadrants, although the upper quadrants of the individual spheres may also contribute to its origins. A society's law and justice manifestations necessarily include both the lower left collective notions of a culture's morality as well as the mechanics of the organized criminal justice system (which resides in the lower right quadrant). Although the mechanics of the system itself, its procedures and processes, are the realm of the LR (lower right, i.e. external-collective) quadrant, the heart of the criminal justice system's punishment may be considered as springing from the LL (lower left) quadrant insofar as it reflects (more or less) the collective morality of a society. This is not to say that it cannot be studied empirically (the volumes of statistics on incarcerations; demographics; sentencing trends, and other quantifiable aspects of it certainly say otherwise), but the essence of law is ultimately driven by collective human introspection (LL) and individual subjective decision-making (UL) (Wilber, 2000).

Morality is one of the primary lines that apply to the field of criminology, as it tracks not only the egocentrism and maleficence of many types of criminal activities, but also the morality of the state's reaction to crime. In this way, then, while morality represents a line of development within the LL quadrant, law may be conceived of as one aspect of the collective level of moral consciousness of a given society.

Therefore, the LL quadrant incorporates two of the basic elements of the process: morality and the law. To these two, one might add the particular cultural inertia of the society as well. As elected officials (LR) who purportedly represent the consciousness (LL) of the community, prosecutors (UR) have some perceived obligations (UL) to represent the public sentiment (LL) in their pursuit of justice vis a vis the criminal justice system (LR).

The Upper Left (Interior-Individual/Intentional) pertains to the inner ruminations and cognitions of individuals (e.g. prosecutors), and maps out their interior landscape with its intellectual capacities, emotions, perceptions; one's own thinking patterns, feelings and perceptions (Wilber, 2007). It is in this realm that prosecutors experience their gut reactions to the crime; the heinousness and savagery of a criminal act that can make it "cry out" for the death penalty, as Sievert put it (1999).

The IT addresses the line of moral development as an overall trend upwards from egocentricity, through conventional norms of social conformity/cohesion, and towards universal awareness and mindfulness of human interconnectedness. There are several stagebased moral theories that work within the IT map to which Wilber alludes (2003). The IT model's exploration of lower left terrain draws (in part) from moral theorists such as Kohlberg $(1973 ; 1977)$ (and later Gilligan's [1982]) pre-convention/conventional/ post-conventional moral stages; Piaget's work on cognitive development (1932/1997); Graves, Beck and Cowan's Spiral Dynamics wave-based developmental "memes" (1996), and Gebser's structures of the collective evolution of human consciousness (1949/1985). Wilber's work reflects a general interpretation of moral ascendancy as the evolution from pre-conventional/ self-interested/egocentric tendencies; to a gradual awareness and concern for conventional/social order/rules and norms, to the postconventional universal awareness/concern/ connectedness to others. It is important to note, of course, that this is only the broadest treatment of these theorists, and does not do justice to the specific assumptions, research and principles behind them. However, it is their overall general direction of development that is of interest here. 
Looking at these from the most basic standpoint, these various interpretations of moral development assume a line of increasing complexity, mindfulness and awareness that begins with self-interest; moves to small group/community and social/state cohesion, and evolves to a more transcendent vision of universal notions of justice and care (and occurring primarily in the Upper Left). This basic unfolding of moral awareness may be ascribed both to individuals (UL) as well as to societies (LL).

In applying this to the prosecution of death penalty cases, then, it becomes a matter of weighing how the punishment may be meted out in a manner consistent with universal notions of human concerns. How can one make ethical decisions of this import from this informed, mindful perspective? Here, Wilber's notion of the Basic Moral Intuition (BMI) may be instructive. The $\mathrm{BMI}$ is the proposition that one strives to "protect and promote the greatest depth for the greatest span" (2000, p. 640). Span, according to Wilber, is the number of units, or individuals within a given context, and depth may refer here to their development and complexity.

\section{Span, Depth and the Basic Moral Intuition (BMI)}

In the BMI, the more complex and developed an organism, the greater depth it is said to have. A horse is "deeper" than a rock. A tree has greater depth than its component cells. Evolution results in greater depth. There are, naturally, fewer of these deeper organisms and they therefore constitute less span. (2000, pp. 9697). When asked about capital punishment in a recorded interview (2005), Wilber has stated that an argument in favor of capital punishment could be supported only if one were certain that the defendant actually committed the crime, and that the BMI were used to preserve the depth of overall society. That is, the viciousness of the crime reflected such an appalling and pathological moral consciousness that the death penalty may be justly implemented as an overall concern for the general provision of a culture or society. In this way, the BMI could make the decision an ethically defensible one (2005). The second condition would obviously difficult to demonstrate, and one should not necessarily take Wilber's statement as his personal view on the death penalty, but rather as a way to approach the issue. Since the BMl's overall aim is to preserve depth, one would have to argue that the DP was necessary to protect greater society and its presumably deeper potential development than the depth of the offender. Furthermore, although all humans may be regarded as having equal "ground value" (that is, all humans have certain inherent dignities and worth), Wilber also distinguishes this from "relative" value. Relative value is determined by an organism's complexity, sensitivity and overall (including but transcending moral) development. With the overall vs. relative value that can be ethically applied to make decisions, Wilber regards the BMI as a pathway to working through difficult quandaries.

The Integral perspective also assumes an everpresent spirit among the quadrants and life forms, but acknowledges that some individuals have "more spirit" than others (2005). In this instance, individuals or societies at higher moral stages that include dimensions of righteousness and care for others, are perceived to have more depth than lower ones, and can be viewed as possessing more "value" in the relative sense. These entities are fewer in number (less span) but represent greater depth. There are more atoms than rock crystals, and more rock crystals than there are mountains. Any human being will represent, relatively, an elevated level of depth (some more than others when one begins to examine moral/spiritual dimensions of development).

It should be noted that Wilber describes the BMI as a pervasive manifestation of spirit that is present at all quadrants and levels of different people, societies and cultures, although it manifests itself differently between pre-rational, rational and post-conventional/ transrational collectives (or fromegocentric to sociocentric to worldcentric stances). Thus, while all people hold some sense of the BMI (it is, of course, supposed to be both basic and intuitive), its unfolding occurs at a level specific to one's current status of moral stage development (2000, p. 641). We argue that it is perhaps best for agents of the criminal justice system to take this as a descriptive, rather than a prescriptive notion. That is, those who represent the power of the state should be aware of the limits of their own apprehension of moral subtleties, and recognize the influence of their own cultural and individual development in enacting the BMI. This is especially so when they are making decisions on behalf of the state to take the life of one its members.

The concept of the BMI applied to the collective has some commonalities with traditional utilitarian ethical theories, which tend to focus on maximizing happiness/good for as many people as possible. Espoused by Bentham as the "greatest happiness" principle, this equation represents a way of assessing 
the greatest good for the greatest number as a general guide for individual moral decision-making (Burns, 2005). However, it should be noted that the BMI also shifts emphasis from protecting volume (span) to protecting depth as well. The greatest number is no longer the overall greatest concern (although all still have value), the greatest sensitivity/depth/complexity across the span is. In this way, the BMI represents a departure from traditional utilitarianism, but maintains its "greater good" focus. What constitutes the "greater good" is simply redefined here as defending the greater embrace of the "wholeness" of a particular society. The components of ground value and relative value (the complexity, depth and worth to the universal rights and needs of others) may serve as a guideline here. If one holds the intrinsic value of a heinous murderer to be above any considerations of relative value, then prosecution of the death penalty becomes a non-starter (since such a posture would hold that all capital punishment is categorically wrong). If, however, if one holds that the damage done to the overall depth and span of a community is better upheld through infliction of the ultimate punishment, then the BMI should be part of the conversation. Prosecutors, as elected by their community to at least partially represent its current collective BMI, may have some obligation to consider it.

It should be reiterated that the BMI or Integral perspective is not, by itself, pro- or anti-death penalty. The weighing of ground vs. relative value to protect maintain depth works well enough in the abstract, but becomes much more difficult when applied to the problem of taking human life in the name of justice. It is not a glib formula by any means. Indeed, one could likely apply Integral Theory in the opposite direction in an argument in favor of abolishing the DP altogether. Certainly, the Integral principles of interconnectedness and mindfulness of the Great Chain would bolster such a proposition. However, the assumption here is not whether the death penalty should be in place in numerous US states (it obviously is) but whether it should be used in particular situations. This is a somewhat different argument. The legal reality of the DP places it squarely in the collective lower quadrants of the map (LL as the moral collective of a society's spirit of justice; LR as the systemic legal machinery of the process).

The DP's legal reality is, of course, not necessarily mean that it is ultimately a moral law, but more indicative of a society's current level of moral development. History, recent and otherwise, is rife with examples of immoral laws. From segregation and slavery laws in the US to a multitude of human rights abuses set forth by various global tyrants to this day, it is clear that governmental legislation alone may make an action lawful, but disastrously immoral and harmful. For these very reasons, moral theorists have socketed blind acceptance of state rule into varied niches of lower-to mid-conventional stage consciousness. It is the development of universal notions of justice and care that tend to characterize the upper level stages of moral consciousness.

Regarding the BMI, it is interesting to note that the general direction of the BMI in its application to the DP aligns fairly well with Sievert's (1999) and Gershman's (1993) discussion on the topic, as referenced above. Both viewpoints stress the need for moral certainty of the offender's guilt, and both take into account the heinousness of the crime. The BMI also adds the element of protecting depth/development, and one may question whether this is to be extrapolated to judging not only the low "relative" value of the offender (in terms of low-consciousness barbarity) but also the assigned "value" of the victim. Is the murder of the righteous, morally and spiritually deep victim more supportive of the ultimate punishment than the murder of a fellow low-conscious psychopath? The BMI would seem to point to this, if only relative worth is weighed and if it is in accord with the societal definitions of depth and span.

\section{DISCUSSION}

In any discursive unfolding of IT and its potential applications to any specific discipline or practice, one finds it similar to the musings of Saul Bellow's protagonist Tommy Wilhelm in his modernist work Seize the Day:

"If you wanted to talk about a glass of water, you had to start back with God creating the heavens and earth; the apple Abraham; Moses and Jesus; Rome; the Middle Ages; gun-powder; the Revolution; back to Newton; up to Einstein; then war and Lenin and Hitler. After reviewing this and getting it all straight again you could proceed to talk about a glass of water." (Bellow, 1996/1956, p. 80).

Because of the ambitious scope and comprehensive depth of IT (the "Theory of Everything," as Wilber called one of his works [2001]), any attempt to focus it on a specific application is necessarily limited in the justice it does to the model. Nevertheless, we have attempted to touch on a few of the basic 
elements of the theory here to provide a basis for discussion.

Judging and assessing the value of human life is, of course, a dicey proposition. One point of the Integral perspective that bears repeating is that one cannot quantify the unquantifiable, and the value of human life is certainly within that realm. Individual prosecutors, when faced with a decision of whether or not to pursue the death penalty routinely go through a series of considerations to arrive at a decision.

In most jurisdictions policymakers have not established a formal policy for prosecutors to follow when making this crucial life or death decision. Prosecutors are left to develop their own policy or worse to make the most important decision a prosecutor can make without any established policy.

The Integral Theory can provide a road map for prosecutors. When applying the Integral Theory to the death penalty we submit the following points:

The BMI represents a basic template of depth and span considerations.

The BMI is a way to approach the fundamental ethical issues involved in implementing the power of the state to impose the ultimate punishment upon those who would exercise barbarity and viciousness against a given collective. The elements of depth and span require consideration of the rights/responsibilities of both the individuals in a society as well as the preservation and safety of the greater community. The overall direction of the BMI is to gauge the value of the rights of the offender's intrinsic worth as a human being against the overall sanctity of the society. In this consideration, the rights of all social members are considered, and the span of citizens within the jurisdiction who rely on the state for protection are part of the picture.

However, the BMI is not a quantitative approach, it is a philosophical heuristic that represents a fairly straightforward tool for making difficult ethical decisions. As such, it is one implement in the proverbial toolbox for prosecutors to use when deciding on the ultimate penalty. The BMI aligns well with established assumptions regarding moral certainty of guilt and the impact of interior/subjective as well as exterior/ objective concerns. The idea of moral certainty of guilt is beyond the standard burden of proof required in a criminal case, beyond a reasonable doubt. However, its use in death penalty case provides a necessary safe guard due to the nature of finality that accompanies the death penalty.

The BMI gives structure to what authors/ practitioners such as Sievert (1999) and Gershman (1993) have already perceived through their experiential knowledge and values. The Integral BMI does not provide specific answers at the individual case level, but it does give direction that surpasses the current vagueness provided by the lower right quadrant's systemic domain of the law and its prescriptive ethics to "seek justice."

The BMI differs from traditional notions of utilitarian ethics in that it does not consider merely the numbers of people who benefit from a particular outcome, but requires an understanding of how the preservation of depth can be best achieved. While the nature of what constitutes "depth" within a particular case can be a thorny issue for prosecutors to decide, it does give some framework to how the decision-making process may take place.

Be informed from all quadrants. In considering the $\mathrm{BMI}$, an all-quadrant approach is necessary in resolving difficult ethical choices, and the decision requires thinking from the prosecutor's own introspection (Upper Left quadrant); the community, cultural, legal and moral considerations (LL); the empirical knowledge of deterrence studies or other manifestations of DP studies (UR), and external empiricism as applied to aggregate data and the blackletter-law machinery of the criminal justice system (LR quadrant).

Some will argue that the moral certainty of guilt should be defined in much the same way that beyond a reasonable doubt or any legal standard of proof is defined. The failure to define moral certainty could lead to arbitrary or capricious decisions to seek the death penalty. If such a definition could be reached at all, it is for another day and not the focus of this paper.

Be informed of lines/levels of human development. Within the quadrants, there are more components of activity. Lines and levels represent the nature of two of these components. Lines (or streams) are the specific personal aspect of evolution under consideration, and levels refer to the ascending stages of that evolutionary line. While Wilber has identified over a dozen streams that reside within the realms of personal development, including cognitive, affective and aesthetic, the primary line under discussion here is the one of morality. 
Although various scholars have mapped out the developmental stages (levels) of morality in different ways, the basic progression from egocentricity to conventional conformity to universal notions of justice and care is a common thread throughout them (Wilber, 2005; 2007).

The prosecutors should maintain awareness of the unfolding aspects of the moral lines associated both within their own upper left subjective contemplation of these issues, but also the collective cultural development of the community which they represent. This last is not to allow cultural norms to dictate the outcomes, or for prosecutors to submit to mob justice. However, as officials elected or otherwise designated to serve a community, there are certain obligations to be mindful of the people whom they purport to represent. It is also necessary to remember that implementation of the BMI is influenced by the current stage of moral consciousness inhabited by the individual prosecutors as well as the community whom they represent.

Seeking justice is a mandate for prosecutors. The lower right quadrant is lacking as it relates to the application of the death penalty. Prosecutors as a result of their education, experience and public personae are acutely attuned to their own introspection, Upper Left quadrant and the community, cultural, legal and moral considerations, Lower Left quadrant. As such, the Integral Theory can be a framework for reaching fair, consistent and justice decisions in the realm of capital punishment.

\begin{tabular}{|c|c|}
\hline $\begin{array}{c}\text { Upper Left } \\
\text { Interior-Individual (Intentional) }\end{array}$ & $\begin{array}{c}\text { Upper Right } \\
\text { Exterior-Individual (Behavioral) }\end{array}$ \\
\hline $\begin{array}{c}\text { Lower Left } \\
\text { Interior-Collective (Cultural) }\end{array}$ & $\begin{array}{c}\text { Lower Right } \\
\text { Exterior-Collective (Social) }\end{array}$ \\
\hline
\end{tabular}

Figure 1: Wilber's four quadrant model (2007). The right quadrants represent exterior, objective, empirical realities. The left quadrants represent interior, subjective experiential realities. The upper quadrants are the individual. The lower ones are the collective.

\section{REFERENCES}

Barnes, K., Sloss, D. \& Thaman, S. (2008). Life and death decisions: Prosecutorial discretion and capital punishment in Missouri. Arizona Legal Studies Discussion Paper No. 08-03; 3rd Annual Conference on Empirical Legal Studies Papers. Retrieved from http://dx.doi.org/10.2139/ssrn.1107456

Barton, R. L. (2013, January 29). How Prosecutorial discretion furthers justice. The Crime Report. Retrieved from http://www.thecrimereport.org
Beck, D.E. \& Cowan, C.C. (1996). Spiral dynamics: Mastering values, leadership, and change. Malden, MA: Blackwell Publishing.

Bellow, S. (1996). Seize the day. London: Penguin Classics. (Originally published 1956).

Bentham, J. (1781). An Introduction to the Principles of Morals and Legislation. Retrieved from http://www.utilitarianism.com/ jeremy-bentham/\#one

Brooks, T. (2003). Kant's theory of punishment. Utilitas, 15, 206-234. http://dx.doi.org/10.1017/S0953820800003952

Burns, J.H. (2005). Happiness and utility: Jeremy Bentham's equation. Utilitas, 17, 46-61. http://dx.doi.org/10.1017/S0953820804001396

Champion, D.R. (2011a).An Integral model of criminality: Aspects of criminal behavior. Insights to a Changing World Journal, 2011 (4), 23-39. Retrieved fromhttp://www.franklinpublishing. net

Champion, D.R. (2011b). White-collar crimes and organizational offending: An Integral approach. International Journal of Business, Humanities and Technology, 1 (3), 34-45. Retrieved from http://www.ijbhtnet.com/

Charleston County Government. (2011). Number of counties by state. Retrieved from http://www.charlestoncounty.org/ stats/bystate.htm

Death Penalty Information Center (2011). The Death Penalty in 2011: Year end report. Retrieved from http://www. deathpenaltyinfo. org/documents/2011__Year_End.pdf

DeMay, J. (1998). A district attorney's decision whether to seek the death penalty: Toward an improved process. Fordham Urban Law Journal, 26, 765-820. Retrieved from http://law. fordham.edu/fordham-urban-law-journal/ulj.htm

Everson, Z. (2009). Excessive cost leads Idaho, Mississippi prosecutors not to pursue the death penalty. Retrieved from http://kcadp.org/2009/11/13/excessive-cost-leads-idahomississppi-prosecutors-not-to-pursue-the-death-penalty/

Frederick, B. \&Stemen, D. (2012). The anatomy of discretion: An analysis of prosecutorial decision making (Document No. 240334). Washington, DC: US Department of Justice. Retrieved from https://www.ncjrs.gov/pdffiles1/nij/grants/ 240334.pdf

Gebser, J.P. (1985). The ever-present origin.(N. Barstad\& A. Mickunas, Trans.). Athens, $\mathrm{OH}$ : Ohio University Press. Original work published 1949.

Gershman, B.L. (1993). A moral standard for the prosecutor's exercise of the charging discretion. Pacelaw Faculty Publications, paper $137 . \quad$ Retrieved from http://digitalcommons.pace.edu/lawfaculty/137/

Gibbs, J.J., Giever, D. \&Pober, K.A. (2000). Criminology and The Eye of the Spirit: An introduction and application of the thoughts of Ken Wilber. Journal of Contemporary Criminal Justice, 16(1), 99-127. Retrieved from http://ccj.sagepub.com http://dx.doi.org/10.1177/1043986200016001006

Gilligan, C. (1982). In a different voice: Psychological theory and women's development. [Kindle Cloud Version]. Retrieved from http://www.amazon.com

Griffin, A. (2012, September 5). Prosecutor spared further grilling in death penalty bias case, Hartford Courant. Retrieved from http://articles.courant.com

Horowitz, J. A. (1997). Prosecutorial discretion and the death penalty: Creating a committee to decide whether to seek the death penalty, Fordham Law Review, 65, 2571-2610. Retrieved from http://fordhamlawreview.org/

Jackson, R. H. (1940). The federal prosecutor. Journal of the American Institute of Criminal Law \& Criminology, 31, 3-5. http://dx.doi.org/10.2307/1137244

Kohlberg, L. (1973). The claim to moral adequacy of a highest stage of moral judgment. Journal of Philosophy, 70, 630-646. http://dx.doi.org/10.2307/2025030 
Kupers, W. \&Statler, M. (2008). Practically wise leadership: Toward an integral understanding. CultureOrganization, 14, 379-400. http://dx.doi.org/10.1080/14759550802489771

Kohlberg, L. \&Hersh, R.H. (1977). Moral development: A review of the theory. Theory into Practice, 16, 53-59. Retrieved from http://www.tandfonline.com/toc/htip20/current\#.UgvrJ5KTjNs http://dx.doi.org/10.1080/00405847709542675

Lafler v. Cooper, 132 S.Ct. 1376 (2012).

Lobsenz, J. (1984). Unbridled prosecutorial discretion, Puget Sound Law Review. Retrieved fromhttp://www.law.seattleu.edu/ academics/journals/law-review

Mangino, M. (2012, April 9). Supreme Court opens door to ineffective plea-bargaining Claim. Pennsylvania Law Weekly. Retrieved from http://www.mattmangino.com/2012/04/supreme-courtopens-door-to-ineffective.html

Marshall, A. (2012, September 16). Death Row in Ohio Shrinking. Cleveland Plain Dealer. Retrieved from http://www. cleveland.com/open/index.ssf/2012/09/death_row_in_ohio_s hrinking_as.html

Martin, R. (2006). Criminology needs an integral vision. AQAL: Journal of Integral Theory and Practice, 1 (1), 235-266. Retrieved from_http://aqaljournal.integralinstitute.org/Public/

Martin, R., Cohen, J.W. \& Champion, D.R. (2013). Conceptualization, operationalization, construct validity, and truth in advertising in criminological research. Journal of Theoretical andPhilosophical Criminology. 5, 1, 1-38. Retrieved from: http://www.jtpcrim.org

Missouri v. Frye, 1329 S.Ct. 1399 (2012).

Ohio Prosecuting Attorneys Association (2012). Death penalty. Retrieved from http://www.ohiopa.org/deathpenalty.html

Oppel, R. (2011, September 26). Sentencing Shift Gives New Leverage to Prosecutors. New York Times. Retrieved from http://www.nytimes.com

Pepinksi, H. \&Quinney, R. (1991). Criminology as peacemaking. Thousand Oaks, CA: Sage.
Petersen, N. \&Lynch, M. (2012) Prosecutorial discretion, hidden cost, and the death penalty: The case of Los Angeles County. Journal of Criminal Law and Criminology, 102, 101-144. Retrieved from http://scholarlycommons.law.northwestern. edu/jclc/

Piaget, J. (1997). The moral judgment of the child. (M. Gabain, Trans.). New York: Simon \& Schuster. (Original work published 1932)

Public Broadcasting Service (2004). Frontline: The plea. Retrieved from http://www.pbs.org/wgbh/pages/frontline/shows/plea/ interviews/

Quinney, R. (1991). The way of peace: On crime, suffering and service. In H. Pepinsky\& R. Quinney (Eds.). Criminology as peacemaking (pp. 3-13). Bloomington and Indianapolis: Indiana University Press.

Sievert, R. J. (1999). Capital murder: a prosecutor's personal observations on the prosecution of capital cases. American Journal of Criminal Law, 27, 105-116. Retrieved from: http://ajclonline.org/

Tennessee Supreme Court (2005). Media guide to Tennessee's legal system. (2005, May). Retrieved from http://www.tncourts.gov/ sites/default/files/mediaguidetotnlegalsystem.pdf

Wilber, K. (1998). The marriage of sense and soul: Integrating science and religion. Boston, MA: Shambhala.

Wilber, K. (2000). Sex, ecology, spirituality: The spirit of evolution. Boston, MA: Shambhala.

Wilber, K. (2001). A theory of everything. Boston, MA: Shambhala.

Wilber, K. (2003). Interview by Tami Simon [Sound recording]. Kosmic Consciousness, Sounds True. Boulder, CO.

Wilber, K. (2007). The Integral vision. Boston, MA: Shambhala.

Witherspoon, T. (2012, October 21). Pursuit of Death Penalty Slows, Waco Tribune, Retrieved March 17, 2013. From http://www.wacotrib.com

Received on 26-08-2013

Accepted on 19-09-2013

Published on 28-10-2013

DOI: http://dx.doi.org/10.6000/1929-4409.2013.02.39

(C) 2013 Mangino and Champion; Licensee Lifescience Global.

This is an open access article licensed under the terms of the Creative Commons Attribution Non-Commercial License (http://creativecommons.org/licenses/by-nc/3.0/) which permits unrestricted, non-commercial use, distribution and reproduction in any medium, provided the work is properly cited. 